\title{
Steering in Uncertain Territory: E-Business, Globalisation and the South African Automotive Components Industry ${ }^{1}$
}

Sagren Moodley

School of Development Studies, University of Natal

\section{ABSTRACT}

Significant and sustainable growth of the South African automotive components industry is contingent upon its ability to compete in a global, e-business-enabled operating environment. The key challenge facing the South African automotive component industry today is one of connectedness to global trade networks, the generation of export volumes and industrial upgrading in global-scale value chains. The domestic components industry will need to leverage e-business for supply chain management and to take part in global trade networks, thus making it urgent for firms to develop IT capabilities. By not making the transition to e-business, component firms may be placing themselves at risk of becoming less competitive in the globally interconnected market, impacting on both their current market positions and long-term viability. If this were to happen, it would have adverse development implications for the country, such as job losses, a decline in revenue growth and an eroded export base.

JEL D20, L62

\section{INTRODUCTION}

The South African automotive components industry currently finds itself under threat as a net result of: (1) increased international competition due largely to rapid and sweeping liberalisation of the South African trade policy regime; ${ }^{2}$ (2) a stagnant domestic market; and (3) the rapid erosion of local sourcing by South African original equipment manufacturers (OEMs) as they become increasingly integrated into the global strategic operations of their parent companies. According to Barnes (2000b: 70), "uncompetitive firms with poor international linkages will disappear from the (components) industry, but those firms that improve their competitiveness and create appropriate linkages with international firms could benefit from burgeoning export sales". The automotive components industry thus urgently needs to reposition itself in global-scale value chains in order to consolidate relationships with OEMs and facilitate exports. 
Transnational companies' (TNCs) control of international production and trade networks makes it extremely difficult for domestic automotive component firms to export independently. Hence, the issue of connectedness to OEMs or to TNC first tier component suppliers has become fundamentally important for the longterm survival and growth of the South African automotive components sector.

From a development perspective, this exploratory study is important because export growth prospects for the components industry hinge increasingly on leveraging information and communication technologies (ICTs) as a means of promoting industrial upgrading within global-scale value chains. In the global automotive industry, TNCs are moving quickly to electronically integrate global supply chains. Most TNCs in the automotive industry are in the process of setting up procurement and supply chain systems. The South African automotive components industry will need to be able to use the Internet to take part in these global production networks, thus making it urgent for domestic firms to develop ICT capabilities. In a few years time, South African component manufacturers may find themselves bidding for business within a global, Internet-connected automotive industry.

The industry's need to enter export markets and to compete with new entrants in the domestic market has become critical to its long-term survival and growth. Flows of information is one critical mechanism through which firms could improve or consolidate their position within the value chain. Gaining access to global-scale trade networks is crucial, and digitally connecting to advanced markets whether it is through complex sourcing relationships or through the export of finished products is critically important. The use of the Internet to coordinate production through domestic and cross-border, inter-firm networks is likely to have a significant impact on the competitiveness of the South African automotive components industry.

The potential of the Internet to create seamless, collaborative supply networks has recently come under academic scrutiny (Gereffi, 2000). Network-oriented ICTs through the compression of space, time and knowledge allow for unprecedented reach, speed and complexity in the management of the automotive supply chain. Theoretically, the Internet holds great potential for revamping traditional supply chains to improve data flow and streamline operations. The challenge for South African automotive component firms is one of how to position themselves within the evolving Internet-connected global supply chains in order to gain competitive advantage and capture value. Drawing on evidence from 19 component firms that are part of the Eastern Cape (ECBC) and KwaZulu-Natal (KNBC) Benchmarking Clubs, we explore the uptake, potential and challenges of e-business for the South African automotive components sector. 
The objective of this exploratory paper is to provide a preliminary analytical foundation to heip focus the policy debate. The paper is structured as follows. First, it provides a synopsis of the key challenges facing the South African automotive components industry. The importance of an outward orientation, global connectedness to transnational production and trade networks, the generation of export volumes and industrial upgrading for the survival of the domestic components sector is stressed. The next section introduces the Eastern Cape and KwaZulu-Natal Benchmarking Clubs, which provides the research population for this study. This section provides an overview of the clubs, and flags some of the supply chain problems experienced by club members. There is, therefore, scope for e-business to streamline the supply chain and reduce information-related uncertainties. The following section presents a conceptual definition of e-business, and discusses its importance for the South African automotive components sector. Next follows some speculation on what kind of impact the Internet is likely to have on the components value chain, especially as it pertains to supply chain management. We believe that this is important considering that e-business is still in an early stage of development, and that the current academic research base is quite thin. Having established the theoretical foundation for the empirical research, the next section reviews the empirical research findings that emanated from the survey of 19 automotive component firms that belong to the Eastern Cape and KwaZulu-Natal Benchmarking Clubs. The final section concludes the study.

\section{THE SOUTH AFRICAN AUTOMOTIVE COMPONENTS SECTOR: AN OVERVIEW}

With the exception of the German-owned OEMs and their global lead source component suppliers, the South African automotive industry is generally characterised by weak global networking links. The inward-orientation of the South African automotive components sector has been fostered by a history of state protectionism and import-substitution industrialisation (ISI) during the apartheid era (Joffe et al., 1995). This inward focus was reinforced by trade isolation, disinvestment and the imposition of economic sanctions during the 1980 s and early 1990s. As a result, nationally-based producers were for a long time insulated from the cut and thrust of international competition. Since the transition period (post-1994), however, the South African automotive industry landscape has been substantially altered by the twin pressures of globalisation and the rapid liberalisation of the trade policy regime. Moreover, in September 1995, the government launched a Motor Industry Development Programme (MIDP) to promote greater integration of the domestic automotive assembly and component industries into the global automotive arena. The primary objective of the MIDP was to improve the international competitiveness of the South 
African automotive sector, and to grow the assembly and component industries, especially through exports.

The South African automotive industry involves multiple players in logistically complex supply chains. The automotive industry can best be described as a "producer-driven" supply chain with multi-layered production systems that are organised hierarchically into tiers (i.e. OEMs, first, second and third tier component suppliers) (Gereffi, 1999) (see Figure 1). Figure 1 clearly shows that with the exception of a few independent aftermarket suppliers, the South African automotive industry is to a large extent controlled by seven OEMs, i.e. Toyota SA, Volkswagen SA, BMW SA, Mercedes Benz SA, Samcor, Automakers and Delta. Currently, the domestic aftermarket provides enough scope and volume to sustain a number of independent component manufacturers of relatively stable technology products such as air filters and batteries. The relationships within and between the automotive value chains tend to be fixed, linear and clearly demarcated. Enormous potential, therefore, exists in creating an environment in which relationships between these players can be more direct, cost efficient and interactive.

The South African automotive industry is the $18^{\text {th }}$ largest in the world, but accounts for less than 1 per cent of the world market. The industry employs about 82000 people and accounts for approximately 6.4 per cent of total manufacturing GDP (Barnes, 2000b: 52). There are approximately 180 component firms in South Africa who supply primarily to the automotive industry, and a further 200 producers who are secondary suppliers (Barnes \& Kaplinsky, 2000a: 801). The South African components sector is being forced to adjust to fundamental changes taking place in the assembly industry, i.e.: (1) the re-incorporation of the previously locally owned and locally controlled domestic assembly industry under global ownership; and (2) the increasing integration of the OEMs into their parent companies' global manufacturing operations (Barnes \& Kaplinsky, 2000a: 799; Moodley, 2001). ${ }^{3}$ Toyota SA and the Delta Motor Corporation are the two exceptions, as they still have majority local ownership and are still largely inwardly focused. ${ }^{4}$ 


\section{Figure 1 South African Automotive Value Chains: A Schematic Overview}

\section{Potential Impact of \\ E-Business on the \\ Automotive Value \\ Chains}

Seamless electronic inter- and intra-firm communication and information flows

ICT architecture based on open networks underlined by partnerships and trust in the value chain

Electronic B2B transactions

High degree of ICT

infrastructure integration and interoperability

High capacity ICT networking capabilities

\section{Digital buryer-supplier linkages}

Internet-enabled supply chain mansgement and logistics

ICT-enabled global connectivity

ICT-enabled value chain upgrading

ICT-enabled imnovation and learning curves

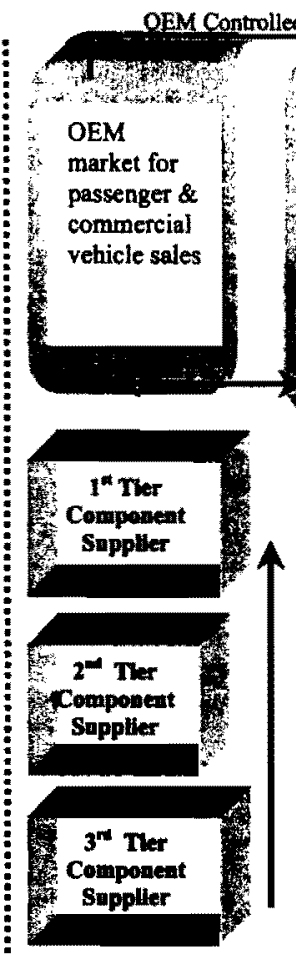

Value Chaln 1

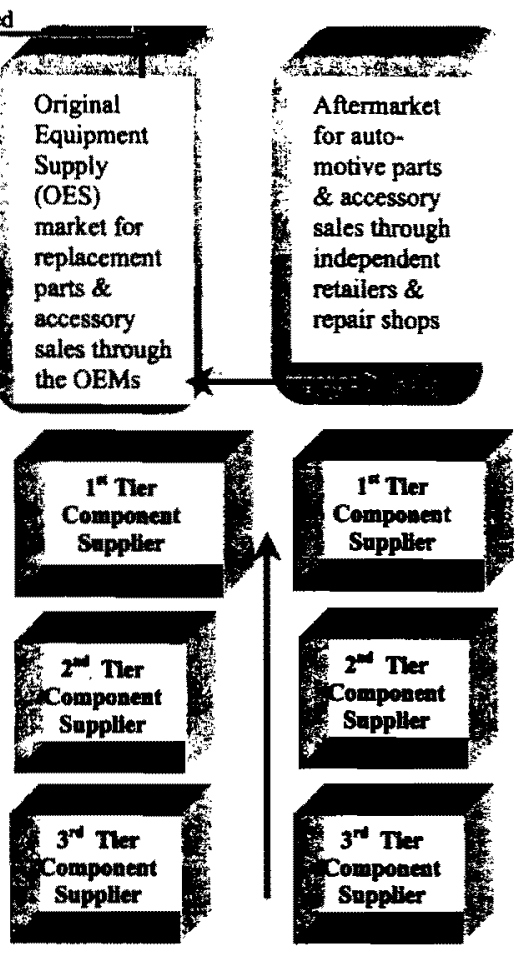

Value Chuin 2

Value Chain 3

Source: Own

South African manufacturers of vehicles and automotive components are becoming increasingly dependent on exports. For example, in 1999, vehicles, parts and accessories comprised 6.5 per cent of total exports; this category did not even feature in 1990 (Finance Week, 27 October, 2000). In the new liberalised trading environment, the domestic OEMs have effectively been set free from local purchasing requirements and now operate in a more or less dutyfree tariff structure. The net effect of this is that there has been a recent trend on the part of domestic OEMs to import components that were previously sourced domestically (Barnes \& Kaplinsky, 2000b: 232). Survival of the South African components industry will, therefore, depend to a large extent on finding a space 
in increasingly intemational production networks, largely controlled by TNCs. Thus, greater connectivity of domestic firms to TNC component firms who effectively control design, marketing and technology developments for high value-added products is critical (Barnes \& Kaplinsky, 2000a, b; Barnes, 2000a, b).

\section{THE AUTOMOTIVE BENCHMARKING CLUBS}

The Eastern Cape (ECBC) and KwaZulu-Natal Benchmarking (KZBC) Clubs have as their prime objective the continuous improvement of their members' operational competitiveness through the generation of comparative domestic and intemational benchmarks. The Clubs are effectively a joint partnership between the Department of Trade and Industry through the Sector Partnership Fund and local automotive component firms. Club members are component firms who are seeking to improve their competitiveness through a learning network. Figure 2 provides an indication of how important the component manufacturers are as a source of employment in both $\mathrm{KZN}$ and the Eastern Cape. Figure 2 illustrates the average employment figures for thirteen (out of a total of nineteen) ${ }^{5}$ club members only. Figure 2 shows that average employment levels peaked in 1996 (455 for the Eastern Cape and 263.5 for $\mathrm{KZN}$ ). Thereafter it has steadily declined, reaching a low of 216.04 in $\mathrm{KZN}$ and 335.0 for the Eastern Cape. Figure 3 indicates the average turnover figures for the club members, and hints at the potential contribution that the clubs make to the regional and national economy. It is important to bear in mind that Figure 3 does not include the turnover figures for 6 component manufacturers. ${ }^{6}$ According to Figure 3, average turnover figures for the Eastern Cape Benchmarking Club peaked in 1997 (R99 737 000), and thereafter it has steadily deteriorated. By contrast, average tumover figures for the $\mathrm{KZN}$ Benchmarking Club has improved between 1996 (R47 345 922) and 1999 (R60 779 499). 
Figure 2 Average number of employees

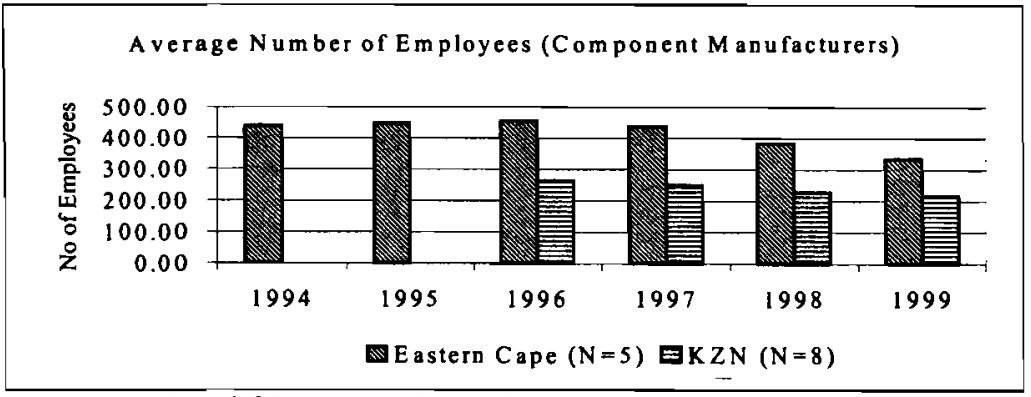

Source: Industrial Restructuring Project (IRP) database

Figure 3 Average turnover

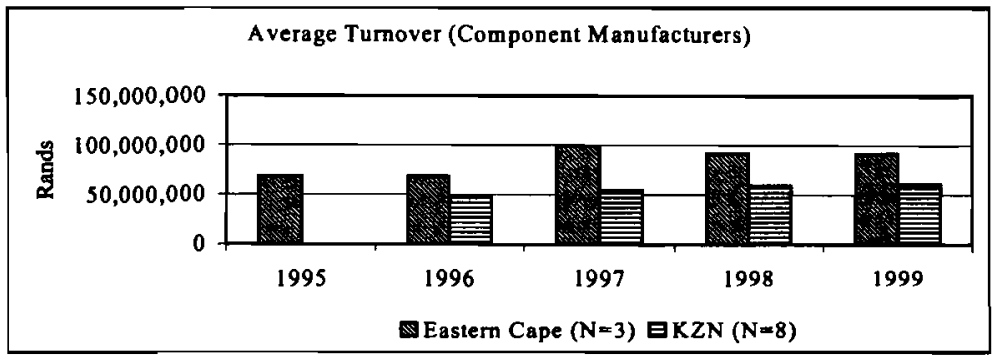

Source: IRP database

We now look briefly at the comparative inventory performance of firms belonging to the Eastern Cape and $\mathrm{KZN}$ Benchmarking Clubs against their international counterparts. This comparison is based on close benchmarking of like-for-like component manufacturers. Inventory level measurements provide a rough proxy for the level of integration in the supply chain. The key inventory control measures considered are:

- Total inventory levels,

- Raw material inventory levels,

- Work in progress levels and

- $\quad$ Finished goods inventory levels.

The objective is to present an outline of the variance in inventory performance amongst club members and their international comparators. Figure 4 clearly shows that whilst improvements in number of days of total inventory have been significant, the general performance of club members is still well below what is required for international competitiveness. The figures suggest that whilst raw 
material (Figure 5) and work in progress (Figure 6) levels have on average improved significantly, finished goods inventory holding (Figure 7) has significantly deteriorated at many firms. This, however, is in most cases, reflective of an increase in exporting growth rather than actual performance deterioration per se, i.e. many club members are holding on to increased finished goods stock because of monthly or bi-weekly shipping schedules to foreign customers.

Nonetheless, Figures 4 to 7 clearly show that club members have a supply chain management (SCM) problem, in that they lag their international counterparts, as it pertains to inventory performance 7 Inventory, excess capacity and stock-outs are the key consequences of information-related uncertainties in the value chain. E-business, in theory, offers club members the possibility of closer synchronisation of the supply chain with the aim of reducing inventory and shortening cycle times. The uptake of this is that firms jointly manage inventories across the supply chain, forecast sales together, and plan collaboratively to keep levels of component and completed product inventory down to a bare minimum.

\section{Figure 4 Number of days of total inventory}

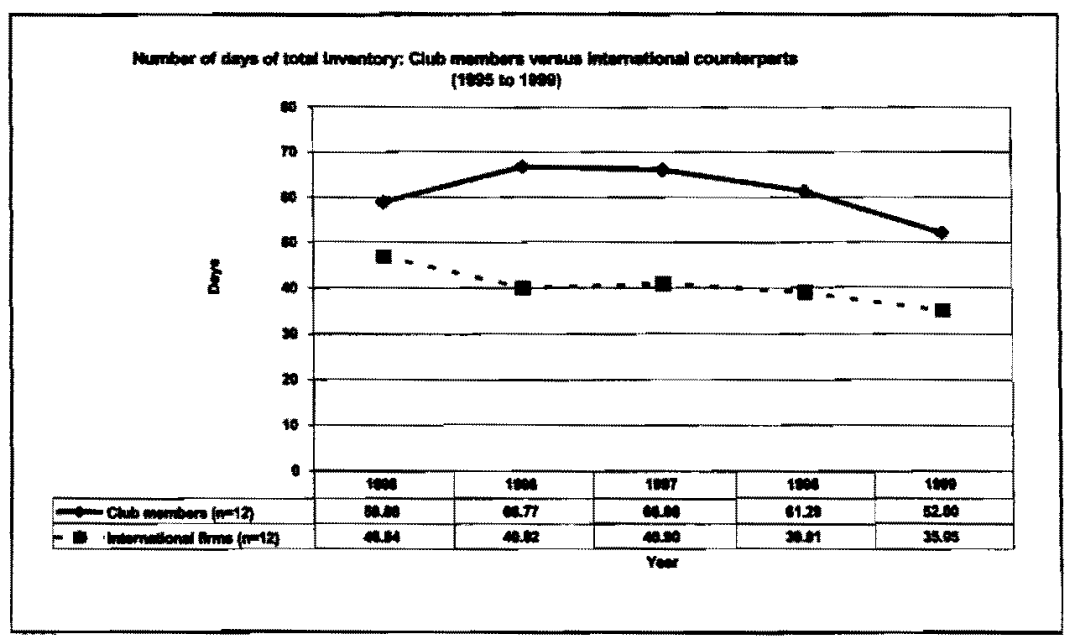

Source: IRP database 


\section{Figure 5 Raw material inventory holding}

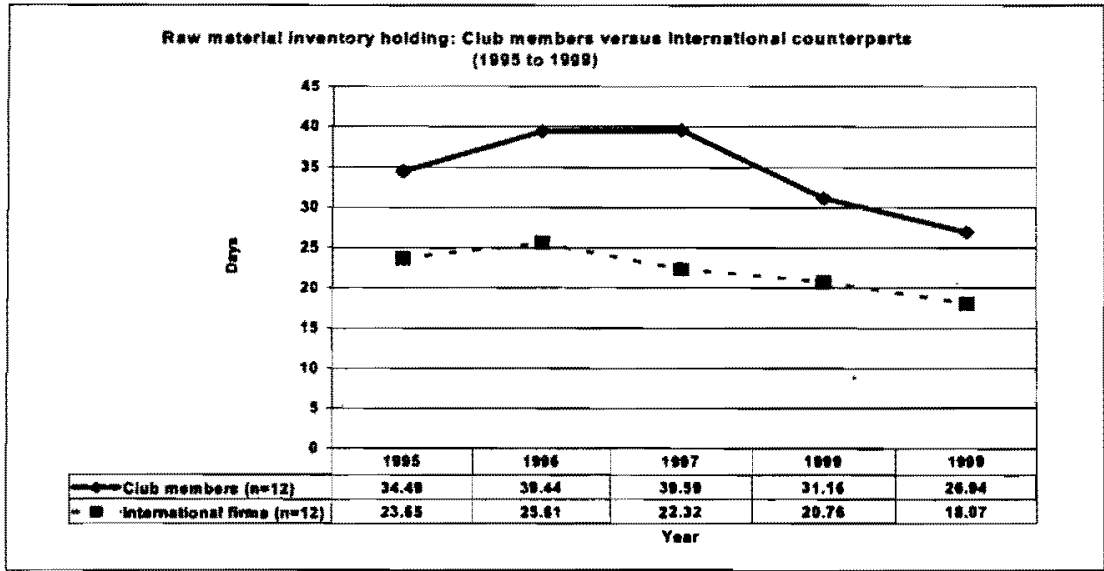

Source: IRP database

Figure 6 Work in progress levels

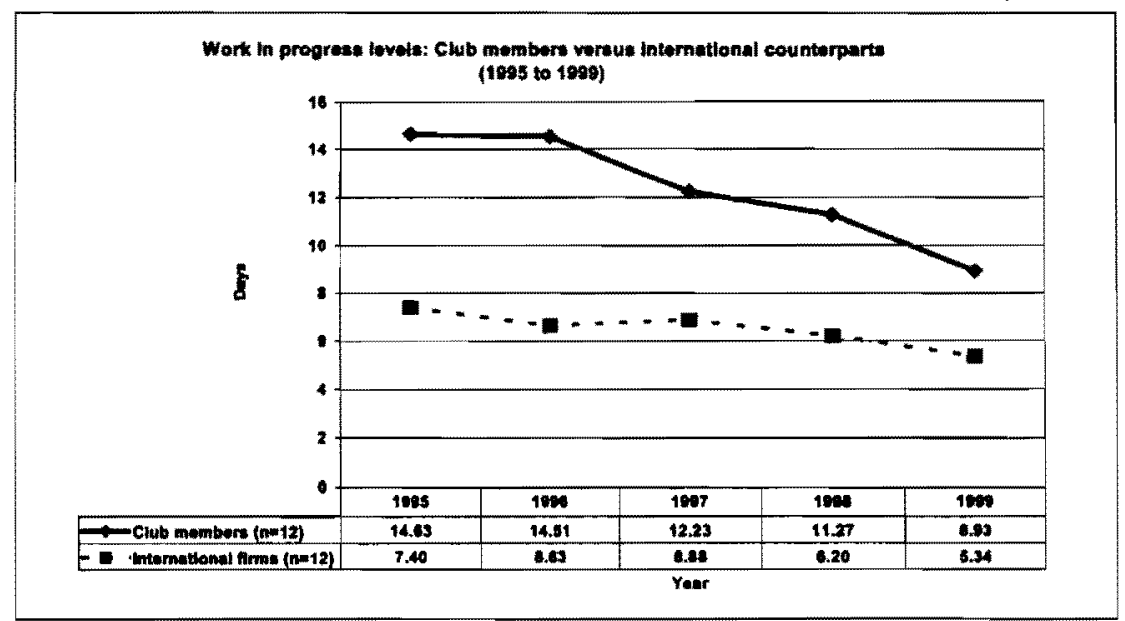

Source: IRP database 


\section{Figure 7 Finished goods inventory holding}

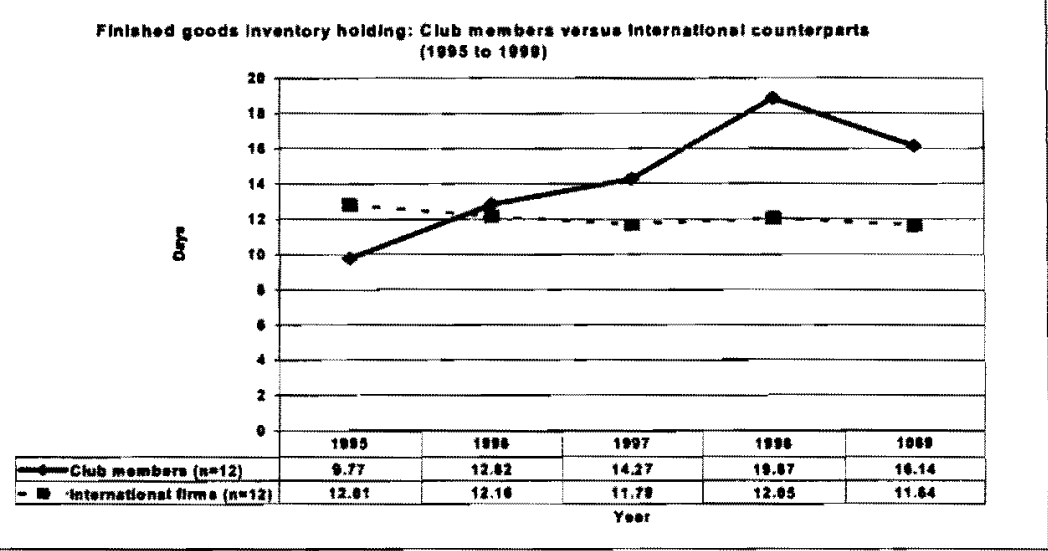

Source: IRP database

\section{C-BUSINESS: TOWARDS A DEFINITION}

Economic globalisation is being driven by pervasive ICT use, deregulation, the opening of markets and global trade expansion (Cohen et al., 2000; Dicken, 1998). ICTs now form an integral part of the accelerated pace of globalisation, linking together nation states into complex webs of transnational exchanges (Castells, 1996; Gereffi, 2000). ${ }^{8}$ The Internet is becoming a key enabler of the global, digitally networked economy. Moreover, economic progress is becoming increasingly knowledge-driven, and information and knowledge are becoming primary wealth-creating assets (Castells, 1996; Evans \& Wurster 2000; Fine, 1998).

Although the precursor of the Internet appeared in the late 1960s, e-business is primarily a product of six significant transformations in the global economy: the globalisation of markets; shift towards an economy based on knowledge and information; the growing prominence of ICTs in the economy; innovations in business organisation and practice (such as Just-In-Time Production, Total Quality Management, Knowledge Management, etc.); the liberalisation of the telecommunications sector in primarily $O E C D$ countries; and technological innovations such as email, the World Wide Web, Internet browsers, and the expansion in the volume and capacity of communication networks (viz. optic fibre, digital subscriber line technologies and satellites). These six factors are closely linked to the emergence of e-business. 
The term e-business has no widely accepted definition. In a very broad sense, it means doing business over the Internet. We define e-business as any form of commercial or administrative transaction or information exchange that takes place via an Internet-based, computer-mediated network. E-business thus entails the application of the Internet to the complete value chain of business processes. E-business places a premium on openness, transparency and trust. The Internet offers a wide spectrum of potential commercial activities and information exchange (Figure 8). This paper focuses exclusively on businessto-business (B2B) Internet interactions (i.e. the shaded block in Figure 8). There are two main reasons for this focus: (1) our concern is primarily with the potential of the Internet for enhancing inter-firm supply chain management, and (2) because current trends seem to indicate that B2B e-commerce will far outstrip that of business-to-consumer (B2C) e-commerce (Intelligence: Business in the Internet Age, May 2000). One of the reasons for the expected exponential growth in B2B e-commerce in the automotive industry is the expected migration of supply chain management from relatively expensive, proprietary (i.e. closed) EDI networks to the open network communication system of the Internet.

B2B e-commerce refers to procurement, logistics and administrative processes occurring between firms. In B2B e-commerce, companies use the Internet to integrate the value-added chain which can extend from the supplier of raw materials to the final consumer. Inter-business e-commerce can be divided into two categories: open marketplace-based trade and direct trade between business partners. The former takes place at various Intemet-based auctions or exchange sites (e.g. Covisint), whilst the latter occurs either through a firm's web site which has an online purchasing function or an EDI-type network. It has been argued that B2B e-commerce is likely to spread globally and grow rapidly primarily because of its potential for: (1) controlling business costs (associated with inventories, sales execution, procurement and distribution), (2) connecting to markets through greater geographical reach, (3) value creation, (4) increasing productivity gains and systemic efficiencies in the value chain, and (5) advanced supply chain management (Cohen et al, 2000; IBM 2000). It appears, therefore, that the South African automotive components industry could, in theory, benefit substantially from adopting e-business. It is to this issue that we now turn. 
Figure 8 e-Business matrix

\begin{tabular}{|c|c|c|c|c|}
\hline & Government & Business & Consumer & Employee \\
\hline Government & $\mathrm{G} 2 \mathrm{G}$ & G2B & $\mathrm{G} 2 \mathrm{C}$ & $\mathrm{G} 2 \mathrm{E}$ \\
\hline Business & $\mathrm{B} 2 \mathrm{G}$ & $\mathrm{B} 2 \mathrm{~B}$ & $\mathrm{~B} 2 \mathrm{C}$ & $\mathrm{B} 2 \mathrm{E}$ \\
\hline Consumer & $\mathrm{C} 2 \mathrm{G}$ & $\mathrm{C} 2 \mathrm{~B}$ & $\mathrm{C} 2 \mathrm{C}$ & $\mathrm{C} 2 \mathrm{E}$ \\
\hline Employee & $\mathrm{E} 2 \mathrm{G}$ & E2B & $\mathrm{E} 2 \mathrm{C}$ & $\mathrm{E} 2 \mathrm{E}$ \\
\hline
\end{tabular}

Source: Own AFRICAN AUTOMOTIVE COMPONENT VALUE CHAIN: THEORETICAL EVIDENCE

In the simple, physical value chain, the flow of goods is linear (Figure 9). The traditional value chain is seen in terms of a series of arms-length, value-adding links from raw materials to end-customer (Figure 9). In other words, the traditional value chain consists of a sequence of activities with clearly demarcated points of input and output. This value chain model (Figure 9) deals with information as a supporting part of the value-adding process, and not as a source of value itself. Contrast this with the Internet-enabled value chain (Figure 10) where the value-adding steps are performed through and with information. 


\section{Figure 9 A simple physical value chain}

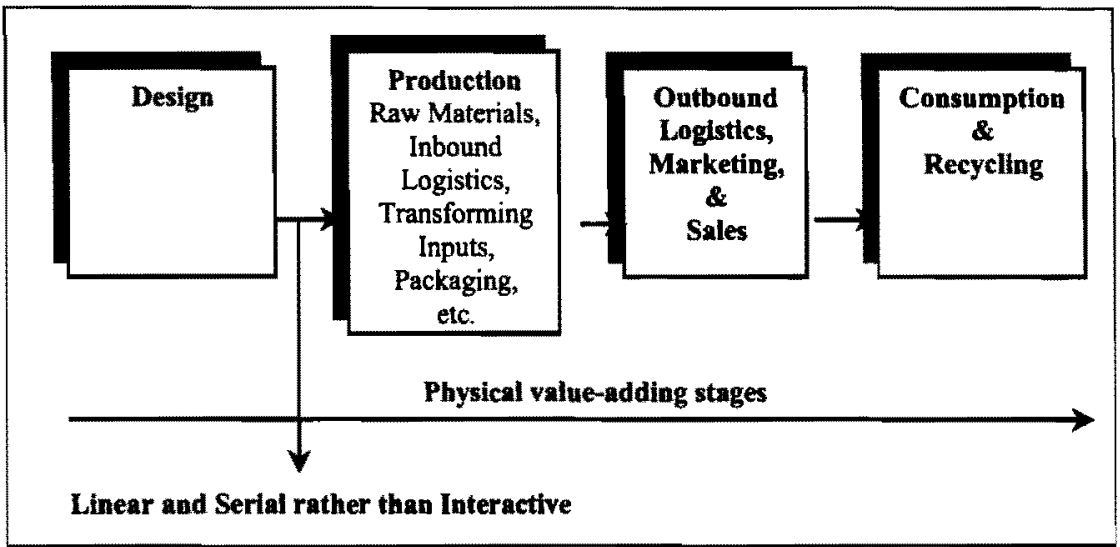

Source: Own

The Internet-enabled virtual value chain, on the other hand, is non-linear (Figures 10 and 11). Rayport and Sviokla $(1994,1995)$ argue that firms today compete in both the physical world of goods (the marketplace) and the virtual world of information (the marketspace). To quote Rayport and Sviokla (1995: 83), the virtual value chain consists of "a matrix of potential inputs and outputs that can be accessed and distributed through a wide variety of channels". With the virtual value chain, information can be captured in real-time at all stages of the value chain, and can be analysed electronically to improve performance at each stage of the value chain, and co-ordinate across it. In a value chain that is completely networked, the Intemet connects every node in the value chain (i.e. the "pull" system becomes operational) (Figure 10). Materials are pulled through the supply chain ultimately by customer request. The logic being that firms should hold minimum inventory and to make just what is needed when it is asked for and not before. 


\section{Figure 10 A virtual corporate value chain}

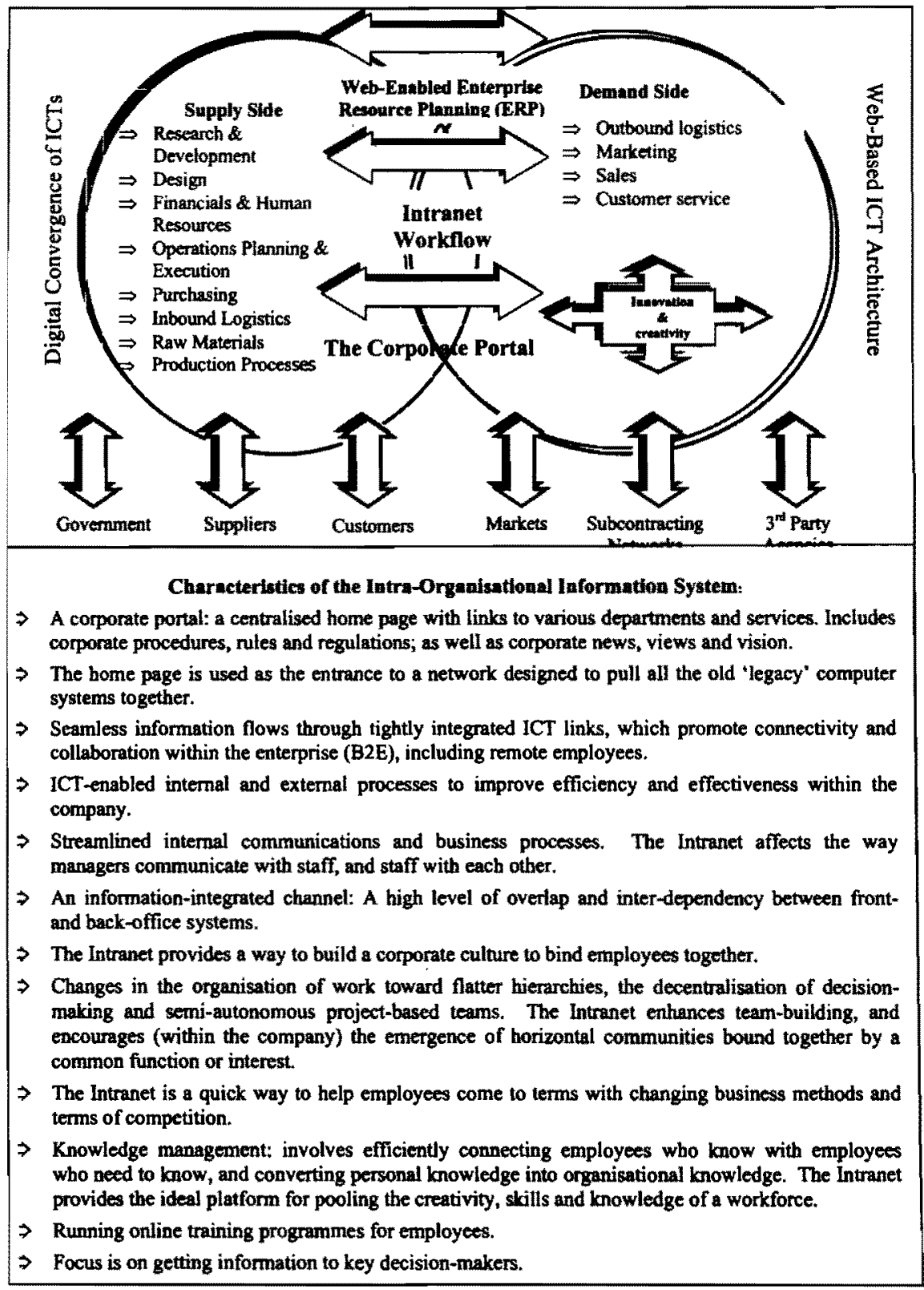

Source: Own 
Gereffi (2000: 2) argues that: "The new digital era of globalization is characterized by an explosion in connectivity that is melting the informational glue that holds corporate value chains and global value chains together". With virtual integration, the links are no longer stand-alone, rather there is a proliferation of strategic, information-defined inter-relationships between the various players in the value chain (Figure 12). Cross-enterprise virtual integration blurs the traditional boundaries and roles of the players in the value chain (Figure 12). The linkages between firms are likely to become more fluid; interactive; pervasive; customised; spontaneous; and potentially, mutually beneficial. Further, the digital links enable the firm to become more flexible and responsive to change. The virtual yalue chain should be seen as an integrated system (Figure 11) rather than as "a set of discrete though related activities" (Figure 9) (Rayport \& Sviokla, 1995: 78). Firms use the Internet to integrate the value-added chain which can extend from the supplier of raw materials to the final consumer (Figure 11).

Figure 11 An integrated value chain

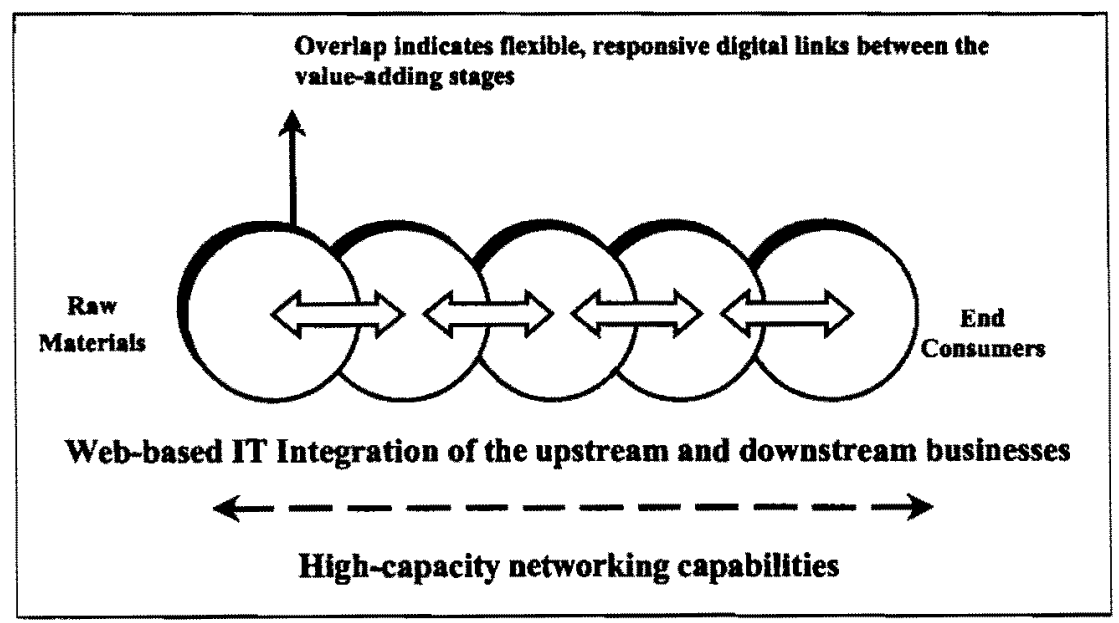

Source: Own 


\section{Figure 12 e-Business-enabled extended enterprise}

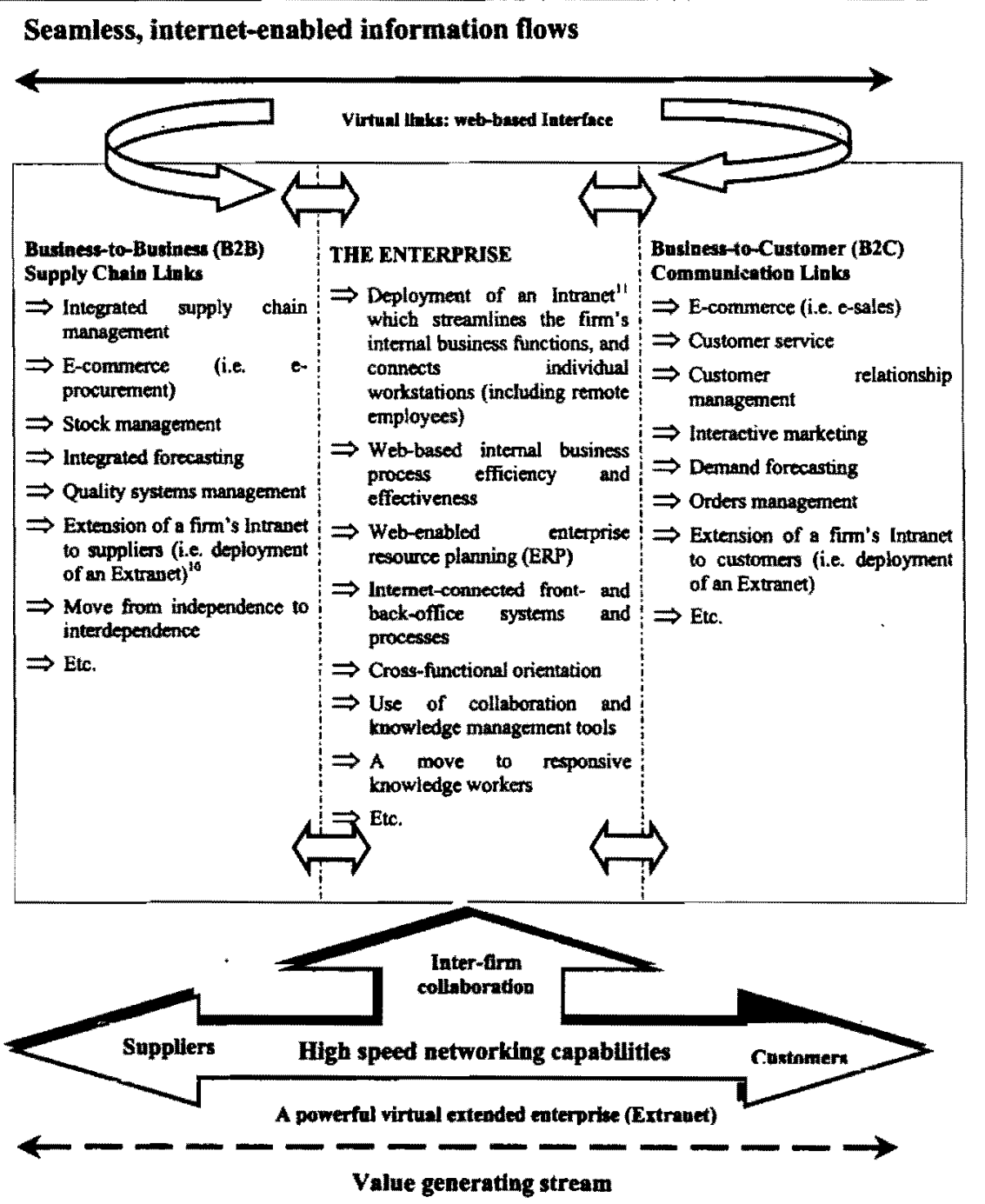

Source: Own 
Figure 11 illustrates how the integrated Internet-based systems in place provides firms with the ability to visualise their value chains from end-to-end, i.e. as an integrated whole. The firm can add real value by focusing on what it does best and then collaborating with other firms involved in the overall supply chain. The Internet facilitates collaboration both within and between firms by dynamically sharing information in real-time (Figure 12). Figure 10 illustrates how the Internet enables the networked or virtual organisation to connect, dynamically in real-time, the supply and demand side of the company. Through the use of Intranets, companies link their employees, providing them with a new communication platform, and a new way to access up-to-date information that is relevant to them. The next step would be establishing an Extranet, in which suppliers and customers have access to real-time and relevant information by linking into an enterprise's Internet system. Thus making it easier for the company and its constellation of suppliers, customers and partners to work together more effectively (Figure 12).

The firm focuses on its distinctive capabilities, and then forms strategic alliances with other firms in the overall value chain. Increased dependence upon suppliers thus becomes a requirement of the firm, and has a major impact on the buyer-supplier relationship. For example, in the global automotive industry, the buyer-supplier relationship which has traditionally been armslength and adversarial is now moving towards a closer collaborative relationship, as a defence against the complexity and uncertainty of markets (Humphrey, 1999).

The Internet holds great promise for the South African automotive components sector in three key areas: (1) increasing the efficiency of internal processes (Figure 10), (2) streamlining inter-firm linkages (systemic efficiencies) and (3) connecting to markets (Figure 12). Dell Computer's Internet-enabled build-toorder business model, for example, illustrates the power of a fully integrated Internet-based assembler/production system (www.dell.com; Magretta, 1998). Apart from improving intra-firm and inter-firm process efficiencies, the Internet can also play a key role in facilitating supply chain learning and innovation. B2B Internet-based collaborative interactions and real-time communication is likely to sharpen the competitive edge of the participating firms, reduce information asymmetries, and improve the quality of information embodied in business relationships.

However, there are also risks associated with e-business, i.e. cost cutting, pricebased supplier relationships and competitive switching. Electronic links theoretically make it easier for buyers to begin and end supplier relationships. Component suppliers will lose the protection afforded by familiar inter-firm relationships and the assemblers. and first tier component manufacturers' 
incomplete information about alternative supply sources. The pursuance of short-term price advantages and the concomitant "factory hopping" and "competitive switching", on the part of the assemblers and first tier component manufacturers, is, of course, at odds with upgrading the positioning of South African component manufacturers in local and global-scale value chains. Therefore, the building of trust, loyalty and reciprocity to reduce the threat of opportunism and to make it difficult to break long-term network relationships is important.

\section{EMPIRICAL EVIDENCE}

Table 1 Uptake of e-business $(\mathbf{N}=19)$

E-Business Technology:

Internet

EDI

Web site?

Yes
100.0 per cent

73.7 per cent

63.2 per cent

The Internet is being used mainly for:

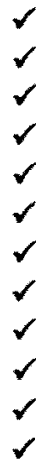

Communication

Order processing

Production

Engineering/Technical

Inventory management

Logistics

Sales

Marketing

Procurement

Services \& support

Management of distribution channels

Research 
Box 1 Key E-business drivers in the ECBC \& KZNBC

\begin{tabular}{|cl|}
\hline$\checkmark$ & Globalisation \\
$\checkmark$ & Trade liberalisation \\
$\checkmark$ & Clostomer requirements \\
$\checkmark$ & Increased competion with customers \& suppliers \\
$\checkmark$ & Connectivity \\
$\checkmark$ & Agility/Business flexibility \\
$\checkmark$ & Joint ventures \\
$\checkmark$ & Market expansion \\
$\checkmark$ & Customer retention \\
$\checkmark$ & Improved efficiencies \\
$\checkmark$ & Cost control \\
$\checkmark$ & Customer \& supplier information exchange \\
$\checkmark$ & Accelerated speed to market \\
$\checkmark$ & The need to streamline business processes \\
$\checkmark$ & Spread of the Internet \\
\hline
\end{tabular}

\section{Box 2 Benefits of the internet according to the ECBC \& KZNBC}

$\checkmark$ Reduces the cost of information

$\checkmark$ Improves inventory management

$\checkmark$ Greater geographical reach: increases domestic and international market access

$\checkmark$ Gives the firm a competitive edge

$\checkmark$ Reduces transaction costs

$\checkmark$ Shortens order-ship-bill cycles

$\checkmark$ Speed combined with flexibility

The previous section reviewed the theoretical evidence supporting e-business in the components sector. We now review the findings that emerged from our empirical survey of 19 South African component manufacturers. According to Table 1, all club members have access to the Internet, but only 63.2 per cent have a web site. The fact that club members connect with the Internet, however, does not mean that Internet use is extensive. Nonetheless, club members claimed to be using the Internet for a wide variety of purposes (Table 1). Club members are only just beginning to use the Internet for supply chain management. Currently, the Internet is used most extensively for intra- and inter-firm communication and for marketing and lead generation, rather than for inter-business transactions. Respondents cited inadequate ICT systems integration and the lack of standards for sharing B2B e-commerce data as the main barriers to fully-fledged e-business.

The researchers conducted an Internet survey of club members' web sites, the results of which show that they are invariably not much more than a front end, 
an online catalogue with orders being emailed, faxed in, and/or taken over the telephone. Customers are unable to check, for example, on service call status, order shipping status and delivery information via the Internet. Four firms use their web sites to take orders and deliver products but have not added any capabilities such as customisation or interactivity to distinguish the service from other types of direct selling. This does not necessarily constitute e-commerce per se because the firms have not developed a fully transactional Internet sales channel. It would appear as if too much emphasis is being placed on establishing a web presence and too little stress is placed on ensuring that the ICT infrastructure is able to support online procurement, trading, marketing and customer sales. Most of the club members are at the stage of basic online "brochureware". Companies have developed static information on a web site, with minimal ability for any interaction beyond email, company background, and in a limited number of cases, the placing of orders.

A substantial 73.7 per cent of club members have an electronic data-interchange (EDI) system in place (Table 1). EDI entails considerable investment in dedicated software and in establishing proprietary networks. For inter-firm communications to take place effectively, buyers and suppliers need matching software and hardware, a common language for communications, a standard layout for documents and a common communication network. A major limitation is the one-to-one nature of EDI transactions. Therefore it is not suitable for companies engaged in occasional (or ad hoc) purchases, or even for regular low-volume business. This is exactly the kind of business that SMEs are involved in. The major drawback with EDI is that it makes it uneconomical to link small suppliers into the system. The cost and supply chain management advantages of EDI creates a tendency for large companies to purchase from suppliers with existing, compatible EDI links.

These forces tend to narrow and concentrate supply chains within a quasicooperative framework, which could, in principle, limit the scope of a firm's sourcing options. Notwithstanding this, those companies which have experience using EDI will probably make the transition to Internet-based ebusiness to streamline the supply chain faster than companies with no EDI experience. In this sense, $\mathrm{B} 2 \mathrm{~B}$ e-commerce via the Internet should be seen as an extension of the existing EDI network. In contrast to the private interactions of the EDI structure, the new virtual, open marketplace is likely to increase competition amongst suppliers and push down purchasing prices.

Box 1 indicates the key drivers for e-business in the South African automotive component sector, as identified by the club members themselves. Box 2 lists what club members perceive to be the major benefits of the Internet. This would seem to suggest that club members are, by and large, quite positive about 
the need for e-business, especially regarding the strong forces promoting a rapid uptake of e-business (Box 1) and the expected benefits of Internet use (Box 2).

Table 2 reveals that Internet-enabled supply chain management is very much in its infancy in the benchmarking clubs. The sluggishness of these companies is reflective of the caution with which enterprises view an ICT tool that is still developing. Many club members feel that a misplaced step into the B2B ecommerce space will not just result in the loss of substantial investment, they fear that they are also "betting the firm" on the move.

Integrating functions across businesses, such as workflow arrangements in a supply chain situation, is predicated on working, integrated internal systems. Table 2 reveals that many component manufacturers do not have fully automated and integrated back and front office systems. A major challenge for the sector is, therefore, one of converging legacy ICT systems with the Internet. The supply chain efficiencies promised by the Intemet are dependent on full Intemet-based integration of the value chain, offering a broad range of collaboration and integration between the trading partners. Reaching this ideal is going to be expensive and requires the sort of industry-wide co-operation not generally prevailing in the South African automotive component industry today. Component suppliers embarking on a fully Internet-enabled system at this early stage in the development of e-business, might find the return on investment to be quite low. In other words, the benefits might not justify the costs incurred in the short-term. But as more suppliers and customers use the Internet to webenable their front- and back-office systems (intemal functionality) (Figure 10), and to connect with their trading partners (collaboration functionality) (Figure 12 ), the benefits of $\mathrm{B} 2 \mathrm{~B}$ e-commerce are likely to become more pronounced.

E-business has to be placed in a relative context, i.e. how fast is adoption compared to competitors. If the rate of B2B e-commerce uptake is lower than that of competitors, this may result in declining value-added and market shares. Until sufficient numbers of their main customers (both domestic and foreign) and suppliers participate in e-business initiatives, there is little incentive for individual firms to develop a web-based customer and supplier interface, and to become engaged in e-business themselves. 


\section{Table 2 Internet-enabled SCM $(\mathbf{N}=19)$}

$\Rightarrow \quad$ Use of the internet for SCM

Yes

$\Rightarrow$ Do your suppliers' have access to real-time information

of your company's sales and stock levels?

Yes

$\Rightarrow$ Do your customers" have access to real-time information of your company's stock levels?

Yes

$\Rightarrow \quad$ Are your firm's internal operations electronically integrated with that of your customers?

Yes

$\Rightarrow \quad$ Are your firm's internal operations electronically integrated with that of your suppliers?

Yes

$\Rightarrow$ Does your company have the e-business capacity to access your suppliers":

Production Capacity?

Available inventory?

Lead Times?

Delivery Flexibility?

$\Rightarrow \quad$ Are your front- and back-office systems electronically integrated?

Yes

$\Rightarrow$ Does your company require suppliers to make use of e-business technologies?

Yes

$\Rightarrow$ Does your company have a supply chain development Programme Yes

$\Rightarrow$ Does your company use e-business technology for B2B procurement? Yes

$\Rightarrow$ Does your company use e-business technology for B2B sales?

Yes 
Unlike the TNC first tier suppliers, domestic first tier suppliers are not taking responsibility for upgrading and coordinating their own supply chains. In his survey of 46 South African component suppliers, Barnes (1998) found that there was very little supply chain development activities from first tier suppliers down to the second and third tier suppliers. Moreover, Barnes and Kaplinsky (2000a: 805) describe the supply chain upgrading activities of the South African OEMs as "modest". This means that possibilities for upgrading the ICT capabilities of component suppliers, especially lower-tier firms, are very limited. This is likely to constrain the widespread diffusion of e-business in the automotive components sector.

The issue of online $\mathrm{B} 2 \mathrm{~B}$ trading exchanges has recently received a great deal of attention in the automotive industry; especially with the launch of Covisint, the giant Detroit-based global automotive virtual marketplace for procuring car components, supplies, services and information. ${ }^{9}$ Only 36.8 per cent of club members are presently part of an online B2B trading hub, but it must be stressed that actual trade via the hubs have, thus far, been very limited (Table 3 ). Nonetheless, club members listed a number of benefits that are likely to emerge from these unified B2B supply chain enterprise networks (Table 3). Club members, however, also recognised a number of possible risks associated with Internet-based B2B trading exchanges (Table 3). Further, club members stressed three main conditions for a trading hub to be successful: (1) openness and transparency; (2) trust and loyalty; and (3) a critical mass of value chain participants.

E-business is not yet a strategic imperative in the South African automotive components sector. The majority of firms in the industry are unable to support e-business ventures today, because they do not have the integrated customer and supplier ICT interfaces in place (Table 2). Box 3 lists the barriers to the adoption of e-business, that have been identified by club members. We, however, believe that the primary e-business impediments are: (1) the armslength and adversarial nature of the relationships that currently exist between value chain participants, both vertically and horizontally; (2) the nature of the automotive value chain, namely that it is overwhelmingly cost-driven rather than innovation and knowledge-driven; (3) a pervasive "wait and see what happens" mindset on the part of club members; and (4) evolutionary path dependencies which have locked firms into an insular, inward-oriented way of thinking. The latter, for instance, manifests itself in firms' reluctance to bring their customers, suppliers and business partners inside the "corporate machine". What is needed therefore is a new strategic direction in the industry, which is likely to entail a sea change in business mindsets. 
Table 3 Internet-based B2B trading hubs $(\mathrm{N}=19)$

$\Rightarrow$ Is Your company linked to an Internet-based B2B trading exchange?

$\begin{array}{ll}\text { Yes } & 36.8 \% \\ \text { No } & 63.2 \%\end{array}$

$\Rightarrow$ What are the benefits of the B2B trading exchange?

$\checkmark$ Sets standards

$\checkmark$ Cuts costs

$\checkmark$ Speed: Internet-based transactions are instantaneous, interactive and rich

$\checkmark$ Supply chain efficiency: enables direct interaction between manufacturers and suppliers, eliminating the need for intermediaries. This is likely to reduce procurement costs

$\checkmark$ Market transparency: by being brought into one open platform, suppliers will be able to bid for contracts they may not previously have known about

$\checkmark$ Improves operating efficiencies

$\checkmark$ Economies of scale: the system should enable buyers with similar requirements to link together to order large quantities of inputs jointly, creating economies in production that will be reflected in lower purchasing prices

$\Rightarrow$ What are the disadvantages of the B2B trading exchange?

$\checkmark$ Rationalisation of the supplier base

$\checkmark$ Potential oligopolistic control and manipulation by transnational assemblers and TNC $1^{\text {st }}$ tier component suppliers

$\checkmark$ Privacy concerns

$\checkmark$ Pressure on prices

$\checkmark$ Threat to established partnerships, relationships \& alliances

$\Rightarrow$ What are the main conditions for a successful B2B trading hub?

$\checkmark$ Openness \& transparency

$\checkmark$ Trust \& loyalty

$\checkmark$ A critical mass of participating firms 


\section{Box 3 Barriers to the adoption of e-business (ECBC \& KZNBC)}

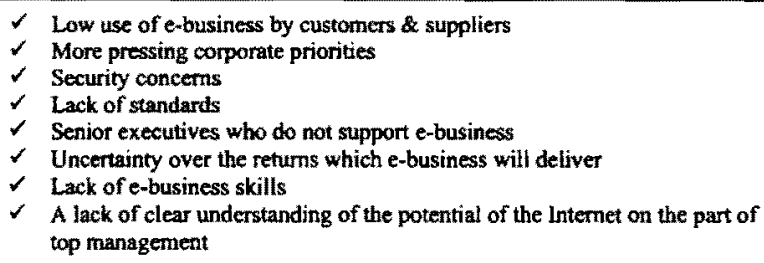

Table 4 Levels of e-business development

\begin{tabular}{|c|c|c|c|}
\hline Levels & 1 & 2 & 3 \\
\hline Sphere & $\begin{array}{l}\text { Functional } \\
\text { orientation }\end{array}$ & $\begin{array}{l}\text { Integrating } \\
\text { across } \\
\text { functional } \\
\text { departments } \\
\end{array}$ & $\begin{array}{l}\text { Cross-enterprise } \\
\text { involvement }\end{array}$ \\
\hline Rationale & $\begin{array}{l}\text { Departmental } \\
\text { focus } \\
\text { The purchasing } \\
\text { \& sales depart- } \\
\text { ment, using EDI } \\
\text { Individual } \\
\text { departments } \\
\text { developing } \\
\text { specific Internet } \\
\text { applications, } \\
\text { e.g. a marketing } \\
\text { website. }\end{array}$ & $\begin{array}{l}\text { Integrated } \\
\text { business } \\
\text { activities via } \\
\text { Internet/ } \\
\text { Intranet } \\
\text { applications. }\end{array}$ & $\begin{array}{l}\text { - A virtual ecosystem that } \\
\text { connects employees, } \\
\text { suppliers and customers } \\
\text { by extending existing } \\
\text { EDI. } \\
\text { The Extranet aims to: } \\
\text { build trust and increase } \\
\text { customer satisfaction; } \\
\text { increase collaboration } \\
\text { and knowledge sharing } \\
\text { between customers and } \\
\text { suppliers; and maximise } \\
\text { synergies to lower costs, } \\
\text { improve efficiencies and } \\
\text { increase quality. } \\
\end{array}$ \\
\hline Levers & $\begin{array}{l}\text { Technological } \\
\text { infrastructure } \\
\text { and software } \\
\text { applications }\end{array}$ & $\begin{array}{l}\text { Business } \\
\text { processes } \\
\text { (process effi- } \\
\text { ciencies } \\
\text { within the } \\
\text { firm) }\end{array}$ & $\begin{array}{l}\text { - Cultivating knowledge } \\
\text { workers } \\
\text { Developing and } \\
\text { exploiting intellectual } \\
\text { capital to create } \\
\text { opportunities } \\
\text { - Building relationships }\end{array}$ \\
\hline
\end{tabular}


The progression of component firms to higher levels of e-business capabilities is likely to be slow and incremental. There are two critical success factors of ebusiness, centred around the networking of internal and external business interactions, which component suppliers will need to seize and rapidly exploit in order to be globally competitive. Firstly, strengthening the bonds between an enterprise and its value chain through an Internet-based system is important. Apart from enhancing inter-enterprise electronic communication, firms will also need to focus on their intra-organisational connectivity in order to tie transactional flows together within the organisation. Currently, most of the component firms' prime focus is still on a functional orientation (Level 1 in Table 4) or on operational efficiency across the enterprise (Level 2). None of the firms are using e-business to increase the organisation's effectiveness outside the enterprise by linking across the Internet with suppliers and customers to create virtual supply chains (Level 3).

\section{CONCLUSION}

In the relatively small, captive South African market, competitiveness has previously revolved more around marketing effectiveness and price competition than production and systemic efficiencies. The small scale and volumes of the South African market perhaps made the viability of fully-fledged business information systems questionable (Moodley, 2002). However, the current pressures of globalisation and the challenge to direct overseas market expansion underscores the importance of e-business for the local component manufacturing industry as a means of acquiring a competitive edge over rivals. The integration of ICT systems within the firm and across the value chain is a necessary but not sufficient condition for global competitiveness.

The critical mass needed to reap positive network externalities is not, as yet, present in the South African automotive components sector. This requires leadership by several of the powerful OEMs and the large first tier suppliers to define e-business standards for all value chain participants, and create incentives that attract more companies to it. The catalytic role that early adopters can play is also critical in promoting the diffusion of e-business in the components sector. In addition, the following four factors will potentially lead to a quicker adoption of e-business in the components sector: (1) a defensive reaction to competitors engaging in e-business; (2) pressure by OEMs and first tier suppliers that all of their suppliers link into their e-business system as a condition of trade; (3) if online trading portals achieve a critical mass of members and become established as a trading platform of choice; and (4) if the cost-reduction and value creation potential of the Internet begin to be realised in practice. 
The components sector critically needs to be outwardly oriented to generate the economies of scale and scope required for global competitiveness. Significant and sustainable growth of the South African automotive industry is contingent upon its ability to compete in a global operating environment. Moreover, as TNCs integrate the Internet into their cross-border business operations, South African firms nun the risk of being excluded from global value chains if they are unable to establish electronic ties with the major players. The policy challenge for the South African automotive components sector is, therefore, how to use the Internet to:

- leverage, consolidate and deepen their links with the global economy;

- access global Internet-based trading portals;

- take advantage of the potentials of globalisation; and

- exploit the systemic and productivity-enhancing possibilities inherent in e-business.

E-business might well become an order-qualifying criterion which producers need as a prior condition for participating in global markets. E-business then, in theory, could be seen as a competitive advantage when competing for global supply contracts. In the context of upgrading and opening up, e-business capability is likely to become influential in determining export success.

E-business is still at a very early stage in its development, and the notion that Internet application may lead to a sustained higher level of economic efficiency is still very much at the level of theory, and will need to be rigorously explored in practice. Moreover, achieving these efficiency gains is contingent on a number of factors, including: (1) access to e-business systems and the needed skills; (2) firms' willingness to open up their internal systems to suppliers and customers; (3) a significant re-engineering of the firm's current organisational structure, i.e. its complex combination of assets, legacy systems, resources and managerial processes and (4) more generally, a firm's evolutionary path dependencies. By not making the transition to Intermet-based business, South African automotive component firms may be placing themselves at risk of becoming less competitive in the globally interconnected market, impacting on both their current market positions and long-term viability. If this were to happen, it would have adverse development implications for the country, such as job losses, a decline in revenue growth and an eroded export base.

The pressure on automotive component firms to re-organise to tap the advantages of e-business is, currently, not high. This is likely to change soon, as e-business becomes a powerful competitive tool for component suppliers to maintain what Sturgeon (2000) calls "geographic agility" and "output agility". The Internet holds great potential for integrating the backward and forward linkages in the automotive components value chain, and digitally connecting all 
phases of the value chain from raw material supply, to design, production, marketing, distribution, consumption and finally recycling (Figures 10 and 11). Hence, e-business could play an important role in: (1) facilitating (networkbased) dynamic learning and innovation curves in the value chain; and (2) improving the ability of automotive component firms to move to more profitable, knowledge-intensive, higher value-added economic niches in international trade networks. Industrial upgrading could take place through harnessing and exploiting the information flows and learning potential associated with Internet-based buyer-supplier links. Thus, the Internetconnected digital network could, at least in theory, be used to create a new source of competitive advantage for the South African automotive components sector in export-oriented development. That said, though, the benefits of the Internet for the automotive components industry are only potentials, and such potentials have to be sought for and released.

Automotive component firms will have to weigh the importance of protecting existing relationships, which account for most of their current revenue, against the advantages of establishing future strategic positions and revenue streams through e-business. Internet impact can be fully examined only as a long-term phenomenon. Initial assessments, especially at such an early stage of e-business development, are at best inconclusive. There is therefore a need for long-term analytical studies by independent researchers on the impact of the Internet on business relationships in the South African automotive components sector.

OEMs developing long-term obligational relationships and investing in their suppliers' ICT capabilities are critical for crafting a knowledge-intensive value chain upgrading path for automotive component manufacturers in South Africa (Sako, 1992). There is, therefore, an urgent need for OEMs to adopt a conscious policy of building stable, long-term relationships with their suppliers based on the transfer of complex information across the inter-firm link. In other words, stronger inter-firm "informational" and "knowledge-based" relationships between OEMs and their suppliers are essential for component suppliers upgrading into quality-driven market segments which offer high returns. The upgrading challenge appears to be tightly bound up with the e-business challenge of creating dynamic, high performance networking between buyers and suppliers to cope with the "new competition" (Best, 1990; Porter, 1998).

The ideal situation is when a company's Internet-based infrastructure supports all aspects of the extended electronic enterprise, enabling the firm to interoperate and collaborate with any number of business partners (Figure 12). In the South African context, fully Internet-enabled supply chain models are a long way off. There is no blueprint or silver bullet that firms can take to be ready for e-business. They need, however, to go beyond the traditional view of just 
looking at their own corporate capabilities; and understand that their growth and profitability will increase by managing and improving the end-to-end process that delivers products to the customers. The Internet is not in itself a panacea or a quick-fix solution for all supply chain difficulties, rather the idea is to use the technology's reach and ubiquity to enable firms to get closer to their employees, customers, suppliers and business partners.

This does not mean that e-business capabilities will, in and of itself, automatically lead to greater domestic and export sales volumes for South African component manufacturers. The future of the domestic automotive components industry is also heavily dependent on achieving international competitiveness through revitalising internal performance capabilities in conformance with world class manufacturing principles. What it does mean, however, is that a failure by domestic component manufacturers to adopt ebusiness will undermine their ability to survive the onslaught of global competition, and will further squeeze them into the low value-added manufacturing segment of the automotive value chains, where the barriers to entry are low and price-based competition is most intense.

\section{ENDNOTES}

1 The International Development Research Centre (IDRC) of Canada provided the funding for this study. Their generous financial support is sincerely appreciated and hereby acknowledged. I am grateful to Raphael Kaplinsky of the Institute of Development Studies, University of Sussex, for his constructive comments on an earlier draft. The remaining errors, omissions and weaknesses are mine alone.

2 At a rate much faster than that required by WTO regulations.

3 This is especially true of the German OEMs, i.e. BMW, Mercedes Benz and Volkswagen.

4 Toyota SA is $72.2 \%$ locally owned, and the remaining $27.8 \%$ is owned by the Toyota Motor Corporation of Japan. Delta, on the other hand, is $51 \%$ locally owned, and $49 \%$ is owned by General Motors (Barnes and Kaplinsky 2000a: 799).

$5 \quad 12 \mathrm{KZN}$ club members and 7 Eastern Cape club members.

6 Some club members regard turnover figures as private. Hence, the missing cases.

7 SCM examines how information can be used to change how and when products are moved to increase efficiency. Companies use SCM to link sales, marketing, distribution, manufacturing processes, and customers, suppliers and business partners together for a more unified approach to the market. The establishment of these links means that firms are able to 
build relationships with customers, suppliers and carriers to more effectively reduce operating cost, improve customers service and expand into new markets.

8 Castells (1996), for instance, writes about a globalised and networked "informational" capitalism.

9 Covisint has been developed by General Motors, Ford and DaimlerChrysler, and has been recently joined by Renault-Nissan (www.covisint.com).

10 Internet-based networks for use by a company and its business partners.

11 Internet-based network for company-use only.

\section{REFERENCES}

1 BARNES, J. (1998) "Competing in the Global Economy: The Competitiveness of the South African Automotive Components Industry", CSDS Research Report No. 13, Durban: School of Development Studies, University of Natal.

2 BARNES, J. (2000a) "Changing Lanes: The Political Economy of the South African Automotive Value Chain", Development Southern Africa, 17(3): 401-15.

3 BARNES, J. (2000b) "Global Trends in the Automotive Industry: Their Likely Impact on South African Automotive Assembly and Component Manufacturers", Transformation, 43: 52-74.

4 BARNES, J. \& KAPLINSKY, R. (2000a) "Globalization and the Death of the Local Firm? The Automobile Components Sector in South Africa". Regional Studies, 34(9): 797-812.

5 BARNES, J. \& KAPLINSKY, R. (2000b) "Globalisation and Trade Policy Reform: Whither the Automobile Components Sector in South Africa", Competition \& Change, 4: 211-243.

6 BEST, M. (1990) The New Competition, Cambridge, Massachusetts: Harvard University Press.

7 CASTELLS, M. (1996) The Information Age: Economy, Society, and Culture, Vol. I: The Rise of the Network Society, Oxford: Blackwell.

8 COHEN, S.J., DELONG, B. \& ZYSMAN, J. (2000) "Tools for Thought: What is New and Important about the "E-Conomy", BRIE Working Paper No. 138, Berkeley: University of California, Berkeley.

9 DICKEN, P. (1998) Global Shift: Transforming the World Economy, London: Paul Chapman.

10 EVANS, P. \& WURSTER, T.S. (2000) Blown to Bits: How the New Economics of Information Transforms Strategy, Boston, Massachusetts: Harvard Business School Press.

11 Finance Week, 27 October 2000. 
12 FINE, C.H. (1998) Clockspeed: Winning Industry Control in the Age of Temporary Advantage, Reading, Massachusetts: Perseus Books.

13 GEREFFI, G. (1999) "A Commodity Chains Framework for Analysing Global Industries", Background Notes for IDS Workshop on the Spreading of the Gains from Globalisation, Institute of Development Studies, University of Sussex, Brighton, UK, 15-17 September.

14 GEREFFI, G. (2000) "Beyond the Producer-Driven/Buyer-Driven Dichotomy: An Expanding Typology of Global Value Chains, with Special Reference to the Internet", Unpublished paper, 14 September, http://www.ids.ac.uk/ids/global/bella.html.

15 HUMPHREY, J. (1999) "Globalisation and Supply Chain Networks: The Auto Industry in Brazil and India", in: Gereffi, G., Palpacuer, F. \& Parisotto, A. (eds.), Global Production and Local Jobs, Geneva: International Institute for Labour Studies, forthcoming.

16 IBM (2000) Making E-Business Deliver: Business Guide, London: Caspian.

17 INTELLIGENCE: Business in the Internet Age, May 2000.

18 JOFFE, A., KAPLAN, D.E., KAPLINSKY, R. \& LEWIS, D. (1995) Improving Manufacturing Performance: The Report of the ISP, Cape Town: UCT Press.

19 MAGRETTA, J. (1998) "The Power of Virtual Integration: An Interview With Dell Computer's Michael Dell”. Harvard Business Review, MarchApril: 73-84.

20 MOODLEY, S. (2001) "E-Business and Supply Chain Management in the Automotive Industry: Preliminary Findings from the Eastem Cape and Kwazulu-Natal Benchmarking Club Surveys", Research Report No. 35, Durban: School of Development Studies, University of Natal.

21 MOODLEY, S. (2002) "Internet-enabled Supply Chain Integration: Prospects and Challenges for the South African Automotive Industry", Development Southern Africa, forthcoming.

22 PORTER, M. (1990) The Competitive Advantage of Nations, London: Macmillan.

23 RAYPORT, J.F. \& J.J. SVIOKLA (1994) "Managing in the Marketspace", Harvard Business Review, November-December: 141-150.

24 RAYPORT, J.F. \& J.J. SVIOKLA (1995) "Exploiting the Virtual Value Chain". Harvard Business Review, November-December: 75-85.

25 SAKO, M. (1992) Prices, Quality and Trust: Inter-Firm Relations in Britain and Japan. Cambridge: Cambridge University Press.

26 STURGEON, TJ (2000) "How Do We Define Value Chains and production Networks?", Unpublished paper prepared for the Bellagio Value Chains Workshop, Rockefeller Conference Centre, Bellagio, Italy.

27 Web sites: www.covisint.com www.dell.com. 